University of Nebraska - Lincoln

DigitalCommons@University of Nebraska - Lincoln

June 1983

ESCHERICHIA COLISTRAINS PRODUCING STREPTOCOCCUS

MUTANS PROTEINS RESPONSIBLE FOR COLONIZATION AND

VIRULENCE

\author{
Roy Curtiss III \\ Robert G. Holt \\ Raul G. Barletta \\ University of Nebraska - Lincoln, rbarletta1@unl.edu \\ James P. Robeson \\ Shigeno Saito
}

Follow this and additional works at: https://digitalcommons.unl.edu/vetscipapers

Part of the Veterinary Medicine Commons

Curtiss, Roy III; Holt, Robert G.; Barletta, Raul G.; Robeson, James P.; and Saito, Shigeno, "ESCHERICHIA COLISTRAINS PRODUCING STREPTOCOCCUS MUTANS PROTEINS RESPONSIBLE FOR COLONIZATION AND VIRULENCE" (1983). Papers in Veterinary and Biomedical Science. 27.

https://digitalcommons.unl.edu/vetscipapers/27

This Article is brought to you for free and open access by the Veterinary and Biomedical Sciences, Department of at DigitalCommons@University of Nebraska - Lincoln. It has been accepted for inclusion in Papers in Veterinary and Biomedical Science by an authorized administrator of DigitalCommons@University of Nebraska - Lincoln. 
Published in Annals of the New York Academy of Sciences, Vol. 409 (June 1983), pp. 688-696.

Copyright (c) 1983 New York Academy of Sciences. Used by permission.

http://www.nyas.org/annals/index.asp 


\title{
ESCHERICHIA COLI STRAINS PRODUCING STREPTOCOCCUS MUTANS PROTEINS RESPONSIBLE FOR COLONIZATION AND VIRULENCE*
}

\author{
Roy Curtiss III,† Robert G. Holt, Raúl G. Barletta \\ James P. Robeson, $\ddagger$ and Shigeno Saito \\ Institute of Dental Research \\ and \\ Department of Microbiology \\ University of Alabama in Birmingham \\ Birmingham, Alabama 35294
}

\section{INTRODUCTION}

Streptococcus mutans is a principal etiologic agent of dental caries and is likely one of the most ubiquitous bacterial infectious disease agents worldwide. $^{1-3}$ The ability of $S$. mutans to colonize the oral cavity is due to sucroseindependent and sucrose-dependent adherence to the pellicle-coated tooth surface with glucan facilitated aggregation between cells to result in plaque. Cariogenicity is then caused by the ability of $S$. mutans in plaque to metabolize free sugars and both extra and intracellular complex carbohydrates to yield predominantly lactic acid. ${ }^{1-3}$ The $S$. mutans gene products that contribute to colonizing ability and thus virulence include glucosyltransferases, glucanbinding proteins, and a diversity of less well-characterized cell-surface proteins and carbohydrate antigens that may also promote adherence or aggregation.

Until recently, $S$. mutans was unable to be analyzed genetically by classical methods of mutagenesis and gene transfer for mapping and complementation. We thus chose to use gene cloning technologies to introduce $S$. mutans genes into suitable strains of Escherichia coli K-12. S. mutans plasmid ${ }^{4}$ and chromosomal ${ }^{5-7}$ genes are expressed very well in $E$. coll. For example, the $S$. mutans gene for aspartic acid semialdehyde dehydrogenase possesses a very unique promoter sequence region that results in $7 \%$ of the total $E$. coli protein being the product of this one S. mutans gene. ${ }^{5.7}$ Furthermore, S. mutans gene products can substitute for $E$. coli gene products that are missing because of the presence of gene mutations or deletions in the E. coli recipient strain. ${ }^{5.7}$ In that regard, Perry and Kuramitsu ${ }^{8}$ have developed a method for transformation of $S$. mutans strain GS-5 (serotype $c$ ), making it possible to mutate $S$. mutans genes cloned in E. coli, to return them to $S$. mutans and then to examine the effect of a known mutation altering a well-characterized gene product on $S$. mutans virulence. Similarly, we have been able to use antibodies against $S$. mutans gene products made by

*Research was supported by Public Health Service Grant DE-02670 from the National Institute of Dental Research and by a Public Health Service Postdoctoral Traineeship, T32 DE 07026, from the National Institute of Dental Research to Robert G. Holt.

$\dagger$ To whom correspondence should be addressed.

$\ddagger$ Present Address: Laboratorio de Microbiología, Universidad Católica de Valparaíso, Casilla 4059, Valparaiso, Chile. 
recombinant $E$. coli strains to select $S$. mutans mutants lacking that gene product.

We have begun systematically to clone $S$. mutans genes encoding cell-surface proteins and then to determine the contribution of these gene products to the ability of $S$. mutans to colonize the tooth surface. An associated objective is to use some of the $S$. mutans gene products synthesized by recombinant $E$. coli clones for the analysis of the immune response to $S$. mutans and for the development of an effective anti-caries vaccine.

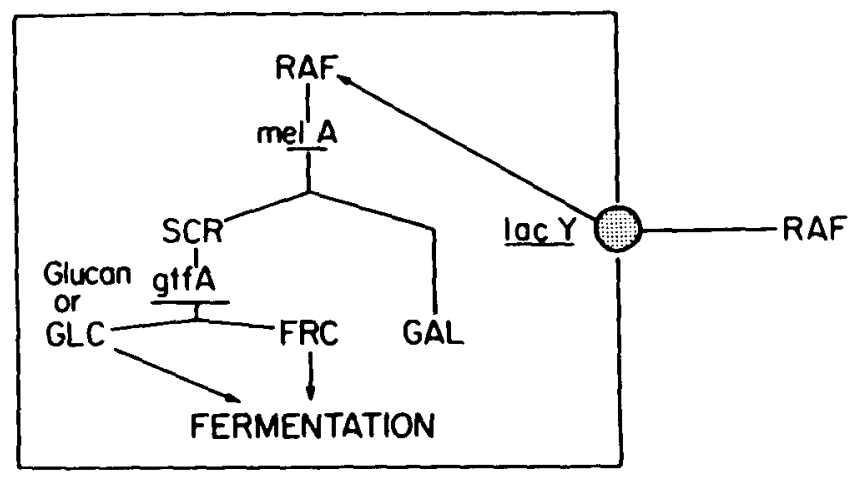

RAFFINOSE

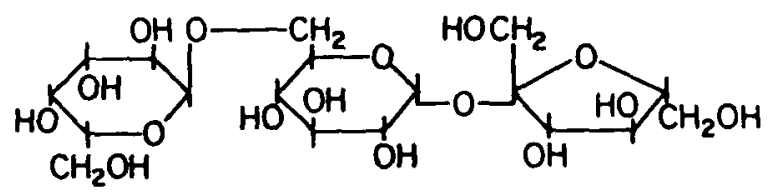

(MELIBIOSE) (SUCROSE)

FIGURE 1. Strategy for successful claning of $S$. mutans genes specifying enzymes for hydrolysis of sucrose into strains of E. coli K-12 (see text).

\section{RESULTS}

Cloning of S. mutans Genes with Sucrose Hydrolyzing Activity

E. coli is unable to metabolize sucrose because of the absence of enzymes with invertase-like activity and furthermore is unable to transport sucrose efficiently across the cytoplasmic membrane. Because we were uncertain whether S. mutans gene products with sucrose hydrolyzing activity would leave the cytoplasm, it was necessary to devise a means to present sucrose to such enzymes in the $E$. coli cytoplasm. FIGURE 1 depicts the strategy for accomplishing this. The trisaccharide raffinose is an $\alpha$-galactoside containing galactose and glucose in an $\alpha-1 \rightarrow 6$ linkage; thus raffinose can be transported across the $E$. coli cytoplasmic membrane by way of the galactoside permease that is the product of the lacY gene. Raffinose can then induce expression of the genes in the mel operon with the melA gene specifying an $\alpha$-galactosidase that cleaves raffinose to yield galactose and sucrose. We thus shotgun cloned S. mutans PS14 (serotype $c$ ) DNA using 


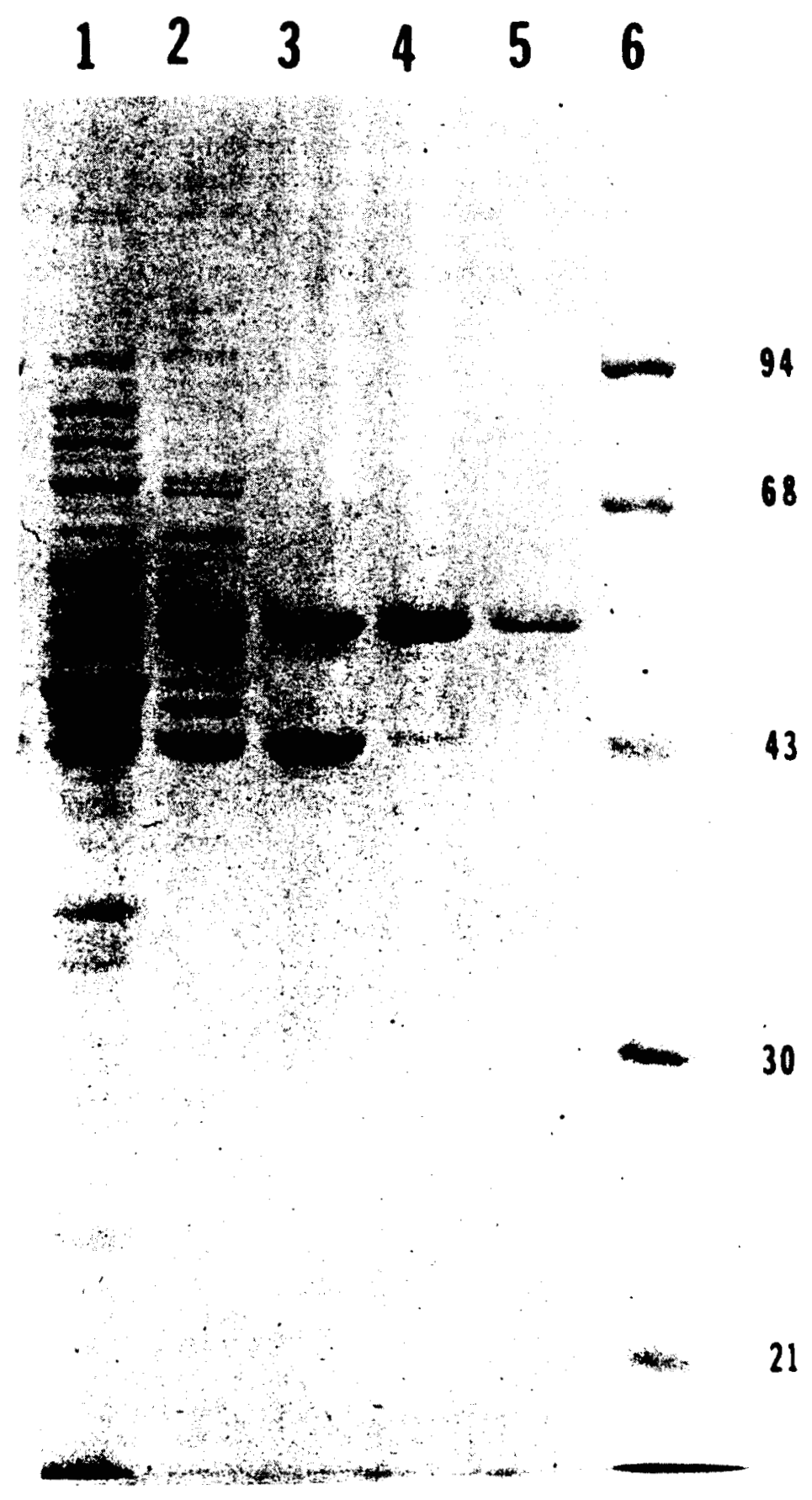

FICURE 2. SDS-polyacrylamide gel electrophoresis of proteins in fractions containing $\mathrm{gtf} A$ enzyme activity at different stages of purification. Activity was measured by generation of reducing sugars from sucrose ${ }^{9}$ Lane 1: crude extract of E. coli K-12 containing pYA601 obtained by sonication followed by sedimentation of cell debris. Lane 2: fractions after chromatography on a DE-52 column. Lane 3: fractions after chromatography on an Ultrogel AcA54 column. Lane 4: fractions after chromatography on an Ultrogel AcA44 column. Lane 5: purified $\mathrm{gtf} A$ enzyme following precipitation with $33 \%$ ammonium sulfate. Lane 6 : molecular mass markers (kdal). 
the pBR322 plasmid cloning vector into an $E$. coli strain possessing a deletion of the gal operon and selected recombinant clones able to grow on raffinose as the sole carbon source. ${ }^{6.9}$ Treatment of $E$. coli cells able to grow on raffinose with toluene led to a linear increase in the amount of reducing sugar generated over time when sucrose was used as a substrate. One of the recombinarit E. coliclones with sucrose hydrolyzing activity contained a recombinant plasmid designated pYA601. Analysis of proteins specified by the recombinant plasmid, pYA601, using purified minicells containing the plasmid, revealed the presence of a 55,000 molecular weight protein encoded by 1730 base-pair fragment of $S$. mutans DNA. Based on the molecular weight of this protein, a strategy was devised for its purification to homogeneity (FIGURE 2). This purified protein could then be used
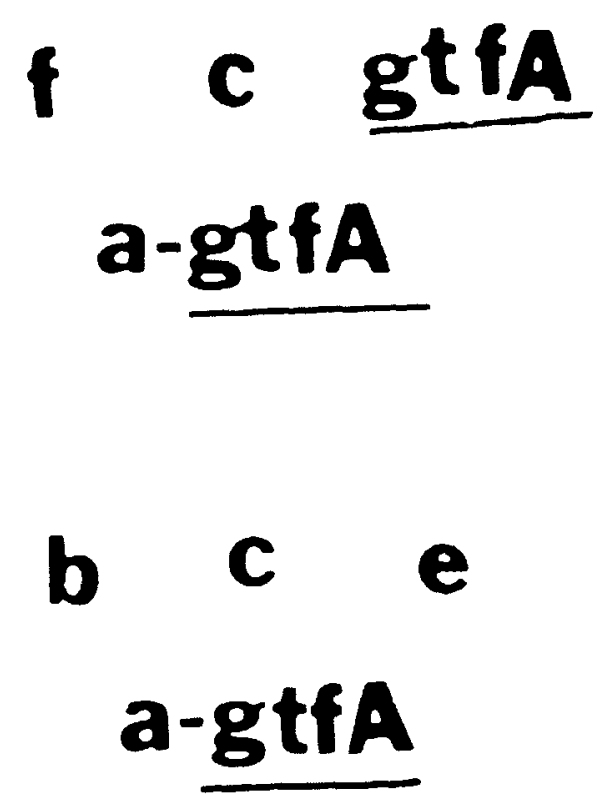

FIGURE 3. Immunodiffusion analysis employing antibodies against purified $\mathrm{gtf} A$ protein produced by $E$. coli (a-gtf $A$ ) and extracts of cell-surface proteins obtained from $S$. mutans strains in serotypes $b, c, e$, and $f$ and the purified $g t f A$ protein from the serotype $c S$. mutans strain, PS14.

to prepare monospecific and monoclonal antibodies against the protein as well as to characterize the protein for its enzyme activity.

The protein encoded by pYA601 is a glucosyltransferase ${ }^{6.9}$ that hydrolyzes sucrose to synthesize a glucan polymer and an equivalent amount of fructose. Antibody against the product of this gene that we have designated $g t f A$ reacts with immunologically identical proteins from serotypes $c$, e, and $f S$. mutans strains and cross-reacts with a protein from serotype $b$ S. mutans (FIGURE 3). No reaction was detected with proteins produced by $S$. mutans serotypes $a, d$, or $g$.

The purified glucosyltransferase has a $K_{\mathrm{m}}$ of $1.2 \mathrm{mM}$ for sucrose, a $\mathrm{pH}$ optimum of about 6.5 and hydrolyzes sucrose to a water-soluble glucan of low 
molecular weight and fructose. This glucosyltransferase does not require a primer, and the protein is transported across the E. coli cytoplasmic membrane into the periplasm without processing or modification. Thus, E. coli containing the pYA601 plasmid can grow on sucrose because sucrose is transported across the outer membrane into the $E$. coli periplasm. E. coli recombinants containing pYA601 synthesize about 100,000 molecules of the gtf $A$ enzyme per cell. This fact accounts for about 3 to $4 \%$ of the total E. coli soluble protein.

\section{Cloning of S. mutans Genes Specifying Cell-Surface Proteins Lacking Enzyme Activity}

DNA from $S$. mutans strain 6715 (serotype g) was shotgun cloned into the cosmid vector, $\mathrm{pJC} 74,{ }^{10}$ so as to reduce the size of the clone bank that would need to be screened for expression of $S$. mutans cell-surface protein antigens. The cosmids packaged in vitro into infectious $\lambda$-phage particles were introduced into an E. colistrain lysogenic for the $\lambda c$ I857 thermo-inducible prophage and plated at $30^{\circ} \mathrm{C}$. Colonies were patched onto an agarose medium containing high titer antisera raised against $S$. mutans cell-surface proteins, and after overnight incubation at $30^{\circ} \mathrm{C}$, the plates were shifted to $42^{\circ} \mathrm{C}$ to cause thermo-induction of the $\lambda$-prophage leading to lysis of cells and release of protein antigens that they contain. ${ }^{11}$ Precipitin rings formed around those colonies expressing a protein antigen reacting with the antibodies in the minimal agarose medium. ${ }^{6.12}$ One of the recombinant clones produced a strong precipitin band and has been studied most extensively. This clone contained the recombinant cosmid, pYA721, that had an 8.3 kilobase insert of S. mutans 6715 DNA. This insert was subsequently cloned into the plasmid vector, pACYC184, to yield the recombinant plasmid, pYA726. ${ }^{12}$ We have designated the gene specifying this surface protein antigen as spa $A$ and have purified the spaA protein to homogeneity both from $S$. mutans and from $E$. coli recombinants. The protein purified from $S$. mutans has an apparent molecular weight of 210,000 by SDS-polyacrylamide gel electrophoresis and of

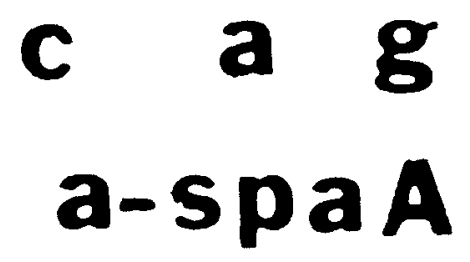

FiguRE 4. Immunodiffusion analysis of cell-surface proteins produced by $S$. mutans serotypes $a, c$, and g against antisera raised to purified spaA protein (a-spaA). It should be noted that proteins from serotypes $c, e$, and $f$ are all identical in regard to response to a-spaA serum as are the proteins produced by serotypes $d$ and $g S$. mutans strains. 
TABLE 1

Presence of antigens Cross-Reacting with 6715 spaA Protein among the VARIOUS SEROTYPES OF $S$. MUTANS

\begin{tabular}{lccc}
\hline Strain & Serotype & Supernatant Fluid ${ }^{\star}$ & Cell Surface $\dagger$ \\
\hline HS6 & $a$ & Yes & Yes \\
BHT & b & No & No \\
Ingbritt & $\mathrm{c}$ & Yes & Yes \\
OMZ176 & $\mathrm{d}$ & Yes & Yes \\
LM7 & $\mathrm{e}$ & Yes & Yes \\
OMZ175 & $\mathrm{f}$ & Yes & Yes \\
6715 & $\mathrm{~g}$ & Yes & Yes \\
\hline
\end{tabular}

*Extracellular protein fractions of the various $S$. mutans serotypes grown in defined media ${ }^{12}$ were prepared from cell-free culture supernatant fluids and were examined for antigens cross-reacting with the spuA protein of $S$. mutans 6715 by immunodiffusion analysis.

$\dagger S$. mutans cells of the various serolypes were grown in defined media ${ }^{12}$ and washed with $5 \mathrm{M} \mathrm{NaCl}$. The presence of cell-surface antigens cross-reacting with the spaA protein of $S$. mutans 6715 was determined by direct immunofluoresence using rhodamine-conjugated a-spaA as a probe.

180,000 when produced by E. coli. E. coli cells with the spaA gene produce $7 \%$ of their total soluble protein as the spaA protein and translocate $60 \%$ of this protein to the periplasmic space..$^{12}$ The spaA protein reacts with antibody against the spaA protein as well as with antibody against the antigen $\mathrm{I} / \mathrm{II}$, purified and characterized from serotype $c S$. mutans strains by Russell, et al. ${ }^{13}$ In addition, antibody purified against the spaA protein reacts with antigen I/II from serotype $c$ and also with antigens produced by serotypes $a, d, e, f$, and $g$, but not by $b$ strains of $S$. mutans (FIGURE 4, TABLE 1). The spaA protein produced by $S$. mutans contains an antigenic determinant not present on the spaA protein produced by $E$. coli recombinants. This phenomenon is possibly due to the absence of carbohydrate antigenic determinants on the E. coli-produced gene product. This hypothesis is currently under test. The spaA protein is found free in the supernatant fluid of $S$. mutans strains grown in FMC medium ${ }^{12}$ (TABLE 1), but is also found to be tightly bound to the cell surface even after washing in $5 \mathrm{M} \mathrm{NaCl}$. By using antibodies directed against the spaA protein, it has been shown that these antibodies will inhibit sucrose-induced aggregation between $S$. mutans cells. Furthermore, $S$. mutans mutants lacking the spaA protein as selected by using antiserum against the spaA protein are also defective in aggregation.

\section{Discussion}

We have found that a diversity of $S$. mutans genes for cell-surface protein antigens from both serotype $c$ and serotype $g$ strains are expressed very well in strains of $E$. coli K-12. Furthermore, most of these S. mutans cell-surface proteins are able to be translocated across the E. coli cytoplasmic membrane into the $\mathrm{E}$. coli periplasm. Because of this fact, we are continuing to identify and characterize other $S$. mutans cell-surface protein antigens produced by recombinant $E$. coli strains. Analysis of these proteins is facilitated by the fact that there are few, if any, E. coli proteins that cross-react with $S$. mutans proteins or vice versa. Monoclonal antibodies against the spaA and $\operatorname{gtf} A$ proteins have been produced 
from hybridomas, ${ }^{14}$ and these monoclonal antibodies are being used to facilitate purification of the spaA and gtf $A$ proteins by immunoabsorbent chromatography. It should be pointed out that relatively satisfactory methods for the purification of these proteins from E. coli, as well as S. mutans, have been worked out.

Other workers have used purified glucosyltransferases ${ }^{15-17}$ and the antigen I/II protein, ${ }^{13}$ also termed $\mathrm{B},{ }^{18.19}$ from serotype $c$ and $\mathrm{g} S$. mutans strains to immunize rats, hamsters, and Rhesus monkeys to evaluate induction of immunity to $S$. mutans-induced dental caries. Some, ${ }^{15.19}$ but not all, ${ }^{16,17}$ of these studies gave promising results.

Because of these previous studies, the purified S. mutans cell-surface proteins are being used in several interrelated investigations. Dr. Michalek, Dr. McGhee, and their colleagues are using these proteins, as well as lipoteichoic acid and type-specific carbohydrate antigens, to screen humans as a function of age for titers of various Ig isotypes in saliva and serum. Both enzyme-linked immunosorbent assays (ELISA) and radioimmunoassays (RIA) have been developed for most of these $S$. mutans cell-surface proteins. These individuals are also being evaluated for caries incidence, and for titers and serotypes of $S$. mutans in plaque. High titers of antibodies, especially secretory IgA, against one or more of these antigens in conjunction with low titers of $S$. mutans in plaque and/or low incidence of dental caries would be suggestive of protein antigens that should be explored for their ability to induce protective immunity against $S$. mutansinduced dental caries.

In this last regard, we are collaborating with Dr. Mestecky, Dr. Michalek, Dr. McGhee, and their colleagues to use purified protein antigens for oral (by gastric intubation) and systemic immunization of mice and gnotobiotic rats to analyze the immune response and evaluate effective immunity to $S$. mutans-induced dental caries. We have also devised a new approach for oral immunization so as to stimulate cells of the Peyer's patches to result in a strong secretory IgA response. Specifically, we are starting with enteric pathogens that are able to attach to and invade cells of the gut-associated lymphoreticular tissue (GALT) and then rendering them avirulent by genetic manipulation as used in our development of the safer $E$. coli host, $\chi 1776$, for recombinant DNA research. ${ }^{20}$ These avirulent pathogens can then be endowed with genetic information to permit high-level production of $S$. mutans cell-surface protein antigens, and because of their ability to attach to and invade cells of the GALT, we anticipate that a secretory immune response against these $S$. mutans protein antigens will be induced. If so, a safe effective vaccine against $S$. mutans-induced dental caries should become a reality. In addition, this method would also be applicable to vaccine construction and immunization to preclude infection by any viral, bacterial, mycotic, or parasitic agent that invades a mucosal surface.

\section{ACKNOWLEDGMENTS}

We thank Sylvia Larrimore and Hettie Murchison for technical assistance and Pat Pierce for help in preparation of this manuscript.

\section{REFERENCES}

1. Newbrun, E. 1973. Cariology. The Williams \& Wilkins Co., Baltimore.

2. Gibbons, R. J. \& J. van HouTe. 1975. Dental caries. Annu. Rev. Med. 26: 121-136. 
3. Hamada, S. \& H. D. Slade. 1980. Biology, immunology, and cariogenicity of Streptococcus mutans. Microbiology Rev. 44: 331-384.

4. Hansen, J. B., Y. Abiko \& R. CuRTiss III. 1981. Characterization of the Streptococcus mutans plasmid pVA318 cloned into Escherichia coli. Infect. Immun. 31: 1034-1043.

5. Curtiss, R. III, E. K. Jagusttyn-Krynicka, J. B. Hansen, M. Smorawinska, Y. Abiko \& G. CARDINEAU. 1982. Expression of Streptococcus mutans plasmid and chromosomal genes in Escherichia coli K-12. In Microbial Drug Resistance. S. Mitsuhashi, Ed.: Vol. 3: 15-25. University Park Press, Baltimore.

6. Curtiss, R. III, J. P. Robeson, Y. Abiko, R. Barletta \& M. Smorawinska. 1982. Synthesis and function of Streptococcus mutans cell surface proteins in Escherichia coli. In Microbiology-1982. D. Schlessinger, Ed.: 253-257. ASM Publications, Washington, D.C.

7. Jagusztyn-Krynicka, E. K., M. SMORAwinska \& R. Curtiss III. 1982. Expression of Streptococcus mutans asparate semialdehyde dehydrogenase gene cloned into plasmid pBR322. J. Gen. Microbiol. 128: 1135-1145.

8. PERRY, D. \& H. K. KuRAMITSU. 1981. Genetic transformation of Streptococcus mutons. Infect. Immun. 32: 1295-1297.

9. Robeson, J. P., R. G. Barletta \& R. CuRtiss III. 1983. Expression of a Streptococcus mutons glucosyltransferase in Escherichia coli. J. Bacteriol. 153: 211-221.

10. Colt.ins, J. 1979. Escherichia coli plasmids packageable in vitro in $\lambda$ bacteriophage particles. Methods Enzymol. 68: 309-326.

11. SKalka, A. \& L. Shapiro. 1976. In situ immunoassays for gene translation products in phage plaques and bacterial colonies. Gene 1: 65-79.

12. Holt, R. G., Y. Abiko, S. Saito, M. Smorawinska, J. B. Hansen \& R. Curtiss III. 1982. Streptococcus mutans genes that code for extracellular proteins in Escherichia coli K-12. Infect. Immun. 38: 147-156.

13. Russell, M. W., L. A. Bergmeier, E. D. ZANDERS \& T. LeHNER. 1980. Protein antigens of Streptococcus mutans: purification and properties of a double antigen and its protease-resistant component. Infect. Immun. 28: 486-493.

14. Daugherty, D. F., D. E. Colwell, R. G. Holt, R. Curtiss III, J. R. MCGhee \& S. M. Michalek. 1982. Fed. Proc. Fed Am. Soc. Exp. Biol. 41: 596.

15. Taubman, M. A. \& D. J. SMITH. 1977. Effects of local immunization with glucosyltransferase fractions from Streptococcus mutans on dental caries in rats and hamsters. J. Immunol. 118: 710-720.

16. Russell, R. R. B. \& G. Colman. 1981. Immunization of monkeys (Macaca fascicularis) with purified Streptococcus mutans glucosyltransferase. Arch. Oral Biol. 26: 23-28.

17. Cohen, B., G. Colman \& R. R. B. Russell. 1979. Immunization against dental caries: further studies. Br. Dent. ]. 147: 9-14.

18. RusselL, R. R. B. 1979. Wall-associated protein antigens of Streptococcus mutans. J. Gen. Microbiol. 114: 109-115.

19. LeHner, T., M. W. Russell, ]. CAlDWEll \& R. SMiTh. 1981. Immunization with purified protein antigens from Streptococcus mutans against dental caries in Rhesus monkeys. Infect. Immun. 34: 407-415.

20. Curtiss, R. iII, D. A. Pereira, J. C. Hsu, S. C. Hull, J. E. Clark, L. J. Maturin, Sr., R. GoldsChmidT, R. MOODY, M. InOUE \& L. AleXANDER. 1976. Biological containment: the subordination of Escherichia coli K-12. In Recombinant Molecules: Impact on Science and Society. R. F. Beers, Jr. and E. G. Bassett, Eds.: 45-56. Raven Press. New York.

\section{Discussion OF THE PAPER}

T. LEHNER (Guy's Hospital, London, England): I am impressed by the crossreactivity between serotypes, except for serotype $b$, which is a rat strain. Can you 
tell us whether there is complete or partial cross reactivity, because you have not shown us all the data on this situation?

R. CURTISS (University of Alabama in Birmingham): Only partial crossreactivity occurs here. Hopefully by using the cloned genes from serotypes $c$, a, and $g$, we will be able to determine what particular domains in this very large protein are shared and those that are dissimilar.

LEHNER: It also appears that this protein has the two antigen determinants that we called antigens I and II. Have you tried to digest away the antigen I component of this antigen I/II complex to leave the antigen II behind?

CuRTISs: Dr. Russell and Dr. Holt in our laboratory have shown that most of the similarity between the spa $A$ proteins from serotypes $c$ and $g$ seem to be in the antigen I component.

LEHNER: I was going to ask about the considerable ease with which you have identified the antigen I/II. What about the antigen III/IV? Have you found any other synthesized by E. coli that you could use?

CURTISS: We have quite a diversity of recombinant clones that produce at least 10 different $S$. mutans cell-surface proteins, and we just have not characterized all of these. They do not have glucosyltransferase activity. One of the problems is that we have not used the antibodies against antigen III or IV to analyze any of our clones. This method might be the simplest way, assuming that they will also be cross-reactive.

L. J. SAIF (Ohio Agricultural Research and Development Center): For your future studies, if you used avirulent enteric strains, do you think that they, indeed, would be able to attach and colonize?

CURTISs: Yes. We are currently using derivatives of Salmonella and Salmonella-Escherichia hybrids. Others have used a Sulmonella derivative that lacks the ability to produce enterochelin, and although it is avirulent, this strain still invades. The real problem with their mutant is that it ends up in the spleen, where it persists for several months. We are developing strains that will not get that far, but hopefully, will just hang up in the Peyer's patches.

M. BLAKE (Rockefeller University, New York, N.Y.): Do you have evidence that your $E$. coli regulates the genes that you are introducing?

CURTISS: Yes.

BLAKE: Do you have any difficulty with a posttranslational modification problem? Do you think that will be a problem in the future?

CuRTISs: The answer to the first question is yes. We do get genes regulated in some cases. Ordinarily, they are constitutively expressed in E. coli, in fact, at a very high level. But, a cluster of three or four genes for galactose metabolism are coordinately regulated in $E$. coli in the same manner as they are in $S$. mutans. Although we thought we had an operon, we did not. There are at least three transcriptional units, and one of the gene products actually is a positive regulator acting to cause increased synthesis of the other enzymes in the pathway.

In terms of posttranslation modification, we now have antibodies that are directed at the unique antigenic determinants on some of these proteins made in $S$. mutans that are not present on the proteins made in E. coli. These antibodies are now being used to screen for cloning of the genes that would cause the proteins in E. coli to be modified. So, by using sequential cloning, we assume that we will be able to demonstrate the synthesis of glycoproteins by recombinant techniques, where we have to introduce genes for several enzymes from the donor-in this case $S$. mutans. This technique should then allow one to look at the different antigens with and without the modifications, in terms of their ability to induce a protective response. 